\title{
Pengembangan E-Modul Berbasis Model Pembelajaran Project Based Learning Pada Mata Pelajaran Videografi untuk Siswa Kelas X Desain Komunikasi Visual di SMK Negeri 1 Sukasada
}

\author{
I Komang Priatna ${ }^{1}$, I Made Putrama ${ }^{2}$, Dewa Gede Hendra Divayana ${ }^{3}$ \\ Pendidikan Teknik Informatika \\ Universitas Pendidikan Ganesha \\ Singaraja, Bali \\ Email : 1215051144@undiksha.ac.id ${ }^{1}$,made.putrama@undiksha.ac.id ${ }^{2}$, hendra.divayana@undiksha.ac.id ${ }^{3}$
}

\begin{abstract}
Abstrak- Tujuan penelitian ini adalah: (1) Untuk menghasilkan rancangan dan mengimplementasikan hasil rancangan pengembangan e-modul berbasis model pembelajaran project based learning pada mata pelajaran videografi untuk siswa kelas $x$ desain komunikasi visual di SMK Negeri 1 Sukasada, (2) Untuk mengetahui respon guru dan siswa terhadap pengembangan e-modul berbasis model pembelajaran project based learning pada mata pelajaran videografi untuk siswa kelas $x$ desain komunikasi visual di SMK Negeri 1 Sukasada.

Jenis penelitian yang digunakan dalam penelitian ini adalah penelitian dan pengembangan (Research and Development) dengan model pengembangan Dick and Carey. Subjek penelitian ini yaitu siswa kelas $X$ Desain Komunikasi Visual di SMK Negeri 1 Sukasada tahun ajaran 2016/2017. Untuk mengetahui respon guru dan siswa terhadap e-modul videografi diperoleh dengan menggunakan metode angket.

Hasil penelitian menunjukkan bahwa: (1) Hasil rancangan dan implementasi e-modul berbasis model pembelajaran project based learning pada mata pelajaran videografi untuk siswa kelas $x$ desain komunikasi visual di SMK Negeri 1 Sukasada dinyatakan berhasil diterapkan berdasarkan beberapa uji yang dilakukan. (2) Hasil analisis data respon guru menunjukkan bahwa, didapatkan rata-rata skor respon sebesar 50 , jika dikonversikan ke dalam tabel penggolongan respon maka termasuk pada kategori sangat positif. Sedangkan untuk respon siswa terhadap pengembangan emodul didapatkan rata-rata skor respon sebesar 67,65 , jika dikonversikan ke dalam tabel penggolongan respon siswa termasuk pada kategori sangat positif.
\end{abstract}

Kata kunci: E-Modul, Videografi, Project Based Learning.

Abstract-The aims of this research are: (1) To develop and to implement e-modul based on project based learning teaching model toward $x$ grade students of design communication visual at SMK Negeri 1 Sukasada, (2) To know both students and teachers response toward the development of e-modul based on project based learning teaching model in videography subject toward $x$ grade students of design communication visual at SMK Negeri 1 Sukasada. The design of this research was $R \& D$ (research and development) research design accompanied with the development model of Dick and Carey. The subject of this research was all X grade students of design communication visual department at SMK Negeri 1 Sukasada academic year 2016/2017. In order to know both teachers and students response toward the e-modul videography, the researcher used questionnaire.

This research shows that: (1) the development of e-modul based on project based learning teaching model in videography subject toward $x$ grade students of design communication visual at SMK Negeri 1 Sukasada have been successfully implemented looking at several tests have been done by the researcher. (2) Based on the analysis of the data of teacher's response, it shows the mean score of 50, if this converts into table of response categorization, it belongs to positive category. Furthermore, based on the analysis of the data of students' response, on the other hand, shows the mean score of 67,65. If it is converted into table of response categorization, it belongs to very positive category.

Keywords: E-Module, videography, project based learning.

\section{PENDAHULUAN}

Sekolah Menengah Kejuruan Negeri 1 Sukasada merupakan salah satu sekolah menengah kejuruan Seni dan Teknologi di kabupaten Buleleng yang bertanggung jawab dalam mengembangkan minat dan bakat yang dimiliki oleh peserta didik. SMK 1 Sukasada memiliki beberapa program keahlian salah satunya adalah program keahlian desain komunikasi visual, terdapat pembelajaran khusus di dalam jurusan ini yaitu pembelajaran produktif. Pembelajaran produktif merupakan pembelajaran yang harus ditempuh oleh peserta didik sesuai dengan kompetensi dan keahlian masing- 


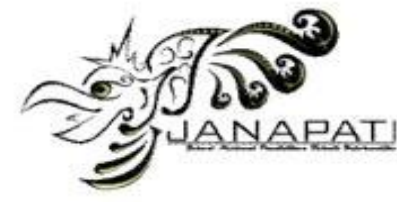

masing, dimana selama menempuh mata pelajaran produktif siswa harus mencapai kompetensi-kompetensi yang telah ditetapkan oleh sekolah. Salah satu kompetensi keahlian yang termasuk mata pelajaran Produktif pada jurusan Desain Komunikasi Visual yaitu Videografi, dimana pada mata pelajaran produktif Videografi ini keahlian yang diberikan kepada para peserta didik adalah keahlian mempersiapkan proses Videografi dari proses pra-produksi, produksi sampai dengan proses pasca-produksi.

Berdasarkan observasi awal yang dilakukan terhadap guru yang mengampu mata pelajaran videografi, didapatkan beberapa permasalahan yang masih menjadi kendala proses belajar mengajar selama ini yaitu 1) kurangnya sumber belajar berupa modul ajar/ buku khusus videografi yang terstruktur dengan baik sebagai panduan dalam proses belajar mengajar di sekolah maupun di luar sekolah, 2) siswa hanya mengandalkan materi dari guru karena susah mencari materi yang sesuai dengan tuntutan kurikulum. Selain itu berdasarkan angket yang di sebar kepada 20 siswa kelas X Desain Komunikasi Visual dari dari total jumal 22 orang, dapat diketahui bahwa 1) $70 \%$ siswa tidak memiliki modul ajar videografi dan 30\% siswa lainnya memiliki modul bersumber dari internet, 2) $65 \%$ siswa merasa alat dan sarana belajar belum membantu proses belajar, 3) $60 \%$ siswa merasa media belajar yang digunakan selama ini belum membantu. Selain sering kali siswa menemukan masalah dalam pembelajaran tidak mampu mencari solusi secara mandiri selain minta bantuan kepada guru, sehingga sebagian besar proses belajar mengajar masih terpusat kepada guru atau teacher centered. Hal ini berdampak terhadap rendahnya tingkat pemahaman peserta didik selama proses belajar mengajar berlangsung. Sebagaian siswa juga menuturkan mereka perlu sumber belajar yang menyajikan materi secara menarik dan komunikatif dimana materi yang disampaikan bukan hanya berupa teks namun juga berupa gambar bergerak atau video sehingga bisa menarik minat siswa dalam proses pembelajaran.

Dari permasalahan tersebut, dibutuhkan suatu media ajar yang dapat menarik minat dan kemandirian siswa sehingga proses kegiatan pembelajaran yang selama ini bersifat teacher centered atau berpusat pada guru bisa berubah kearah student centered atau berpusat pada siswa sesuai dengan tuntutan kurikulum KTSP. Media ajar juga harus bisa membantu dan memudahkan guru dalam menyampaikan materi dalam proses belajar mengajar sehingga guru tidak kekurangan sumber materi yang digunakan sebagai panduan. Selain itu media ajar harus mudah diakses dan mudah dipelajari walaupun terbatas akan alat pendukung pembelajaran sehingga memungkinkan siswa belajar secara mandiri. Salah satu media pembelajaran yang dapat menjadi solusi atas permasalahan yang sedang dialami jurusan desain komunikasi visual di SMK Negeri 1 Sukasada adalah modul pembelajaran interaktif berupa elektronik modul (e-modul) berbasis web yang dikemas dengan
p-ISSN 2089-8673 | e-ISSN 2548-4265

Jurnal Nasional Pendidikan Teknik Informatika (JANAPATI)

Volume 6, Nomor 1, Maret 2017 berbagai penyajian materi yang lebih konkret, nyata dan dilengkapi simulasi pendukung pembelajaran.

Modul elektronik atau yang biasa disebut e-modul merupakan inovasi terbaru dari modul cetak, dimana modul elektronik ini bisa diakses dengan bantuan komputer yang sudah terintregrasi dengan perangkat lunak yang mendukung pengaksesan e-modul. Media elektronik yang dapat diakses oleh siswa mempunyai manfaat dan karakteristik yang berbedabeda. Jika ditinjau dari manfaatnya media elektronik sendiri dapat menjadikan proses pembelajaran lebih menarik, interaktif, dapat dilakukan kapan dan dimana saja serta dapat meningkatkan kualitas pembelajaran ${ }^{[15]}$. Pengembangan emodul dapat dikembangkan dengan berbagai metode pembelajaran dan bantuan media pendukung lain. Pada penelitian ini digunakan model pembelajaran Project Based Learning. Model pembelajaran Project Based Learning ini dipilih untuk mengubah gaya belajar yang berpusat pada guru menjadi pembelejaran yang berpusat pada siswa dengan cara memberikan ruang kepada siswa untuk menumbuhkan kreativitas sehingga menghasilkan suatu produk sebagai pemecahan masalah yang dihadapi. Keuntungan model pembelajaran Project Based Learning antara lain: (1) Increased motivation, (2) Increased problem-solving ability, (3) Improved library research skills, (4) Increased collaboration, dan (5) Increased resource-management skills ${ }^{[5]}$.

Penelitian e-modul sudah pernah dilakukan sebelumnya oleh peneliti lain, menyatakan bahwa tanggapan mahasiswa terhadap pelaksanaan perkuliahan menggunakan e-modul berorientasi pemecahan masalah adalah sangat positif ${ }^{[9]}$. Penelitian e-modul lainnya juga menyatakan bahwa e-modul mendapatkan penilaian positif dari dikarenakan materi pembelajaran menjadi sangat mudah dipahami oleh siswa, selain itu, pengoperasian modul tersebut sangat mudah, unsur musik dan animasi dinilai dapat meningkatkan motivasi, minat, dan aktivitas belajar para peserta didik ${ }^{[14]}$. Selain itu, e-learning pendukung project based learning berhasil dibangun menggunakan lms moodle dapat digunakan sebagai salah satu alternatif dalam proses belajar mengajar dan $92 \%$ responden menyatakan bahwa e-learning mudah diakses dan sebanyak $76 \%$ responden menyatakan bahwa e-learning mudah digunakan ${ }^{[13]}$

Berdasarkan uraian di atas, adanya pengembangan emodul dalam proses pembelajaran sangat penting karena dapat menambah bahan belajar siswa. Terkait hal ini, peneliti melakukan pengembangan e-modul dalam penelitian dengan judul "Pengembangan E-Modul Berbasis Model Pembelajaran Project Based Learning Pada Mata Pelajaran Videografi Kelas X Desain Komunikasi Visual di Smk Negeri 1 Sukasada”. 


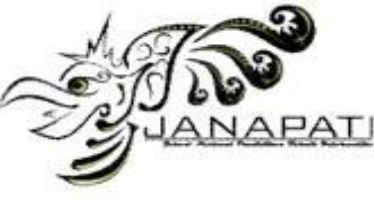

\section{KAJIAN TEORI}

\section{A. Mata Pelajara Videografi}

Mata pelajaran videografi merupakan bagian dari kelompok pelajaran produktif yang ada di kompetensi keahlian Desain Komunikasi Visual yang menerapkan metode pembelajaran dengan proposisi pembelajaran 30\% teori dan $70 \%$ praktik, di mana penugasan dan pendalaman teori dilakukan selama praktik. Videografi adalah mata pelajaran yang berorientasi utama menghasilkan produk video yang bermanfaat. Produk ini dapat dihasilkan melalui penguasaan fakta, konsep, prinsip, dan prosedur dengan baik.

\section{B. Model Pembelajaran Project Based Learning}

Pembelajaran berbasis proyek merupakan suatu model yang menekankan siswa untuk dapat belajar secara mandiri dengan memecahkan masalah yang dihadapi serta siswa juga dapat menghasilkan suatu proyek atau karya nyata. Proyek dalam pembelajaran berbasis proyek tidak ditentukan oleh hasil belajar yang didapatkan oleh siswa saja, namun juga dilihat pada proses dan aktivitas siswa dalam proses pembelajaran sehingga akan berdampak pada meningkatnya hasil belajar siswa $^{[2]}$.

Tabel 1 Sintak Model Pembelajaran Project Based Learning (PjBL) ${ }^{[7]}$

\begin{tabular}{|c|c|c|}
\hline Kegiatan & $\begin{array}{c}\text { Deskripsi Kegiatan/ } \\
\text { Aktivitas Guru }\end{array}$ & Aktivitas siswa \\
\hline $\begin{array}{l}\text { Tahap 1 } \\
\text { (eksplorasi) } \\
\text { Orientasi } \\
\text { masalah }\end{array}$ & $\begin{array}{l}\text { Menyampaikan tema } \\
\text { sesuai dengan Kompetensi } \\
\text { Inti }\end{array}$ & $\begin{array}{l}\text { Mengamati atau } \\
\text { menganalisis suatu } \\
\text { permasalahan } \\
\text { yang diberikan, } \\
\text { mengikuti } \\
\text { petunjuk guru }\end{array}$ \\
\hline $\begin{array}{l}\text { Tahap } 2 \\
\text { 1. Membentuk } \\
\text { kelompok } \\
\text { 2. Merencana } \\
\text { kan } \\
\text { kegiatan } \\
\text { kelompok }\end{array}$ & $\begin{array}{l}\text { 1. Menginstruksikan siswa } \\
\text { untuk membentuk } \\
\text { kelompok (3-4 orang) } \\
\text { 2. Membimbing siswa } \\
\text { mempersiapkan } \\
\text { investigasi } \\
\text { a. Pemilihan topik } \\
\text { b. Membuat peta } \\
\text { konsep atau } \\
\text { diagram } \\
\text { c. Membuat rincian } \\
\text { terhadap tahapan } \\
\text { proses } \\
\text { d. Monitoring kerja } \\
\text { proyek }\end{array}$ & $\begin{array}{l}\text { 1. Membentuk } \\
\text { kelompok (3-4 } \\
\text { orang), } \\
\text { mengikuti } \\
\text { petunjuk guru } \\
\text { 2. Merencanakan } \\
\text { kegiatan } \\
\text { investigasi } \\
\text { a. Pemilihan } \\
\text { topik } \\
\text { b. Membuat } \\
\text { peta konsep } \\
\text { atau } \\
\text { diagram } \\
\text { c. Pembuatan } \\
\text { rincian } \\
\text { terhadap } \\
\text { tahapan } \\
\text { proses } \\
\text { Monitoring } \\
\text { kerja } \\
\text { proyek }\end{array}$ \\
\hline $\begin{array}{l}\text { Tahap } 3 \\
\text { (Elaborasi) } \\
\text { Melakukan } \\
\text { Investigasi }\end{array}$ & $\begin{array}{l}\text { Membimbing siswa } \\
\text { melakukan investigasi }\end{array}$ & $\begin{array}{l}\text { Melakukan } \\
\text { investigasi }\end{array}$ \\
\hline
\end{tabular}

p-ISSN 2089-8673 | e-ISSN 2548-4265

Jurnal Nasional Pendidikan Teknik Informatika (JANAPATI)

Volume 6, Nomor 1, Maret 2017

\begin{tabular}{|l|l|l|}
\hline \multicolumn{1}{|c|}{ Kegiatan } & \multicolumn{1}{|c|}{$\begin{array}{c}\text { Deskripsi Kegiatan/ } \\
\text { Aktivitas Guru }\end{array}$} & \multicolumn{1}{c|}{ Aktivitas siswa } \\
\hline $\begin{array}{l}\text { Tahap 4 } \\
\text { Merencanakan } \\
\text { laporan }\end{array}$ & $\begin{array}{l}\text { Membimbing dan } \\
\text { mengarahkan penyusunan } \\
\text { laporan }\end{array}$ & $\begin{array}{l}\text { Menyusun laporan } \\
\text { hasil investigasi }\end{array}$ \\
\hline $\begin{array}{l}\text { Tahap 5 } \\
\text { (Konfirmasi) } \\
\text { Presentasi } \\
\text { laporan }\end{array}$ & $\begin{array}{l}\text { Memfasilitasi kegiatan } \\
\text { presentasi laporan proyek } \\
\text { dan berperan sebagai } \\
\text { narasumber }\end{array}$ & $\begin{array}{l}\text { Mempresentasikan } \\
\text { laporan kegiatan } \\
\text { proyek }\end{array}$ \\
\hline $\begin{array}{l}\text { Tahap 6 } \\
\text { Evaluasi }\end{array}$ & $\begin{array}{l}\text { Melakukan evaluasi } \\
\text { terhadap laporan hasil } \\
\text { proyek }\end{array}$ & $\begin{array}{l}\text { Mendokumentasik } \\
\text { an masukan- } \\
\text { masukan guru } \\
\text { yang berhubungan } \\
\text { dengan proyek }\end{array}$ \\
\hline
\end{tabular}

\section{Modul Ajar}

Modul merupakan suatu cara pengorganisasian materi pelajaran yang memperhatikan fungsi pendidikan. Artinya, melalui modul suatu pembelajaran diharapkan mampu membawa peserta didik pada kompetensi dasar yang diharapkan. Lebih lanjut, strategi pengorganisasian materi pembelajaran pada modul mengandung squencing yang mengacu pada pembuatan urutan penyajian materi pelajaran, dan synthesizing yang mengacu pada upaya untuk menunjukkan kepada peserta didik keterkaitan antara fakta, konsep, prosedur dan prinsip yang terkandung dalam materi pembelajaran. Untuk merancang materi pembelajaran, terdapat lima kategori kapabilitas yang dapat dipelajari oleh peserta didik, yaitu (1) informasi verbal, (2) keterampilan intelektual, (3)strategi kognitif, (4) sikap, dan (5) keterampilan motorik. Strategi pengorganisasian materi pembelajaran terdiri dari tiga tahapan proses berpikir, yaitu (1) pembentukan konsep, (2) intepretasi konsep, dan (3) aplikasi prinsip. Strategi-strategi tersebut memegang peranan sangat penting dalam mendesain pembelajaran. Kegunaannya dapat membuat mahasiswa lebih tertarik dalam belajar, mahasiswa otomatis belajar bertolak dari prerequisites, dan dapat meningkatkan hasil belajar ${ }^{[8]}$.

Tabel 2 Perbandingan antara Modul Elektronik dengan Modul Cetak ${ }^{[4]}$

\begin{tabular}{|l|l|}
\hline \multicolumn{1}{|c|}{ Modul Elektronik } & \multicolumn{1}{|c|}{ Modul Cetak } \\
\hline $\begin{array}{l}\text { Ditampilkan dengan } \\
\text { menggunakan monitor atau } \\
\text { layar komputer. }\end{array}$ & $\begin{array}{l}\text { Tampilannya berupa kumpulan } \\
\text { kertas yang berisi informasi } \\
\text { tercetak, dijilid, dan diberi cover. }\end{array}$ \\
\hline $\begin{array}{l}\text { Lebih praktis untuk dibawa } \\
\text { kemana-mana, tidak peduli } \\
\text { berapa banyak modul yang } \\
\text { disimpan dan dibawa tidak } \\
\text { akan memberatkan kita dalam } \\
\text { membawanya. }\end{array}$ & $\begin{array}{l}\text { halamannya maka akan semakin } \\
\text { tebal dan semakin besar pula } \\
\text { ual ini akan merepotkan kita } \\
\text { dalam membawanya. }\end{array}$ \\
\hline $\begin{array}{l}\text { Menggunakan CD, USB } \\
\text { Flashdisk, atau memory card } \\
\text { sebagai medium penyimpan } \\
\text { datanya. }\end{array}$ & $\begin{array}{l}\text { Tidak menggunakan CD atau } \\
\text { memory card sebagai medium } \\
\text { penyimpan datanya. }\end{array}$ \\
\hline $\begin{array}{l}\text { Biaya produksinya lebih } \\
\text { murah dibandingkan dengan } \\
\text { modul cetak. }\end{array}$ & $\begin{array}{l}\text { Biaya produksinya jauh lebih } \\
\text { mahal. }\end{array}$ \\
\hline
\end{tabular}




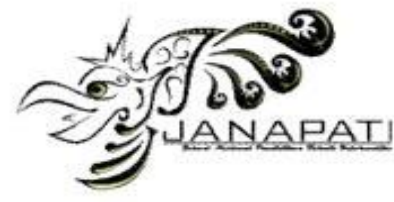

\begin{tabular}{|l|l|}
\hline \multicolumn{1}{|c|}{ Modul Elektronik } & \multicolumn{2}{c|}{ Modul Cetak } \\
\hline $\begin{array}{l}\text { Menggunakan sumber daya } \\
\text { berupa tenaga listrik dan } \\
\text { komputer atau notebook untuk } \\
\text { mengoperasikannya. }\end{array}$ & $\begin{array}{l}\text { Cukup praktis, tidak } \\
\text { membutuhkan sumber daya } \\
\text { khusus untuk menggunakannya. } \\
\text { Daya tahan kertas terbatas oleh } \\
\text { waktu. }\end{array}$ \\
\hline $\begin{array}{l}\text { Dapat dilengkapi dengan } \\
\text { audio dan video dalam satu } \\
\text { bundle penyajiannya. }\end{array}$ & $\begin{array}{l}\text { Tidak dapat dilengkapi dengan } \\
\text { audio dan video dalam satu bundle } \\
\text { penyajiannya Hanya dapat } \\
\text { dilengkapi dengan ilustrasi dalam } \\
\text { penyajiannya. Jika ditambah } \\
\text { dengan video terpisah akan } \\
\text { menjadi paket pembelajaran, } \\
\text { bukan lagi hanya sekedar modul. }\end{array}$ \\
\hline
\end{tabular}

\section{E-modul}

E-modul merupakan seperangkat media pengajaran digital dan non cetak yang disusun secara sistematis dan digunakan untuk keperluan belajar mandiri, sehingga dapat menuntut siswa untuk belajar memecahkan masalah dengan caranya sendiri. E-modul adalah bahan belajar yang dirancang secara sistematis berdasarkan kurikulum tertentu dan dikemas dalam bentuk satuan waktu tertentu yang ditampilkan menggunakan piranti elektronik misalnya komputer atau android. E-modul merupakan alat atau sarana pembelajaran yang berisi materi, metode, batasan-batasan, dan cara mengevaluasi yang dirancang secara sistematis dan menarik untuk mencapai kompetensi yang diharapkan sesuai dengan tingkat kompleksitasnya secara elektronik (bagian dari $e$ learning) ${ }^{[3]}$.

\section{E. Computer Assisted Instruction (CAI)}

Computer Assisted Instruction (CAI) adalah suatu sistem penyampaian informasi/materi pelajaran yang berbasis mikroprosesor yang pelajarannya dirancang dan diprogramkan kedalam media yang interaktif untuk merangsang motivasi belajar siswa $^{[1]}$.

Computer Assisted Instruction (CAI) merupakan salah satu media pembelajaran yang sangat menarik dan mampu meningkatkan motivasi belajar pesertadidik ${ }^{[12]}$.

\section{F. Moodle}

Moodle (Modular Object-Oriented Dynamic Learning Environment) adalah paket perangkat lunak yang diproduksi untuk kegiatan belajar berbasis internet dan situs web. Moodle merupakan salah satu aplikasi dari konsep dan mekanisme belajar mengajar yang memanfaatkan teknologi informasi, yang dikenal dengan konsep pembelajaran elektronik atau $E$ learning. Moodle dapat digunakan secara bebas sebagai produk sumber terbuka (open source) di bawah lisensi GNU. Moodle dapat diinstal di komputer dan sistem operasi apapun yang bisa menjalankan PHP dan mendukung database SQL) ${ }^{[13]}$.
p-ISSN 2089-8673 | e-ISSN 2548-4265

Jurnal Nasional Pendidikan Teknik Informatika (JANAPATI)

Volume 6, Nomor 1, Maret 2017

\section{G. Kerangka Berpikir}

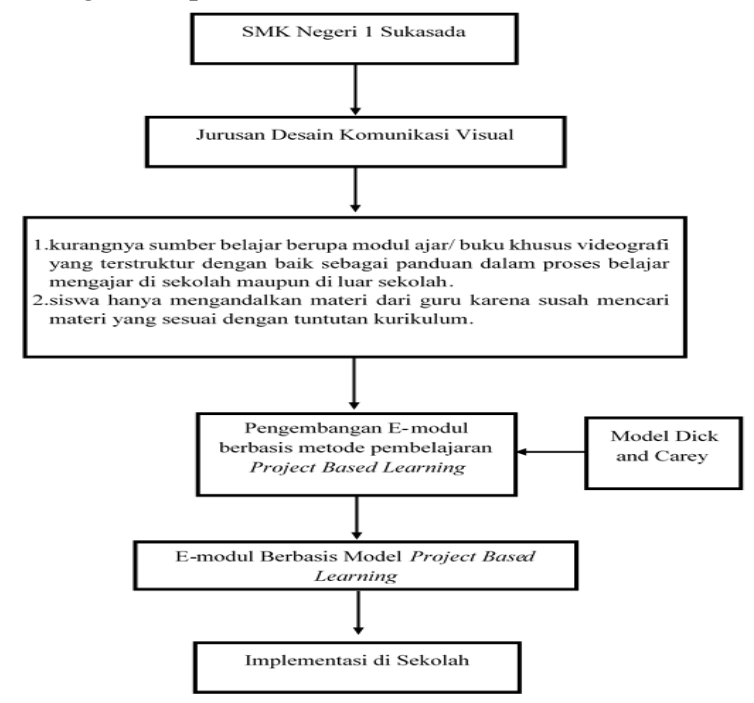

Gambar 1. Kerangka Berpikir Pengembangan E-modul

Berdasarkan hasil observasi di SMK Negeri 1 Sukasada diketahui bahwa ada beberapa masalah yang selama dihadapi oleh jurusan Desain Komunikasi Visual yaitu 1) kurangnya sumber belajar berupa modul ajar/ buku khusus videografi yang terstruktur dengan baik sebagai panduan dalam proses belajar mengajar di sekolah maupun di luar sekolah, 2) siswa hanya mengandalkan materi dari guru karena susah mencari materi yang sesuai dengan tuntutan kurikulum.

Berdasarkan permasalahan tersebut maka peneliti melakukan pengembangan e-modul berbasis metode Project Based Learning sebagai salah satu solusi pemecahan masalah pada kegiatan pembelajaran, diharapkan dapat bermanfaat untuk peserta didik, guru dan sekolah dalam meningkatkan keberhasilan proses kegiatan pembelajaran..

\section{METODOLOGI PENELITIAN}

Penelitian pada Pengembangan E-modul Berbasis Model Project Based Learning Mata Pelajaran Videografi kelas $\mathrm{X}$ Desain Komunikasi Visual di SMKN 1 Sukasada menggunakan jenis penelitian Research and Development. Jenis penelitian ini merupakan penelitian yang menekankan kemampuan penelitian dalam membuat suatu produk baik berupa materi, media, alat dan atua strategi pembelajaran. Penelitian jenis ini merupakan metode penelitian yang digunakan untuk menghasilkan produk tertentu, dan menguji keefektifan produk tersebut ${ }^{[10]}$.

Dalam model pengembangan e-modul ini menggunakan model pengembangan Dick and Carey. Model ini terdiri atas lima tahap, yaitu: (1) menentukan mata pelajaran, (2) analisis kebutuhan, (3) proses mengembangkan draft, (4) skema implementasi media dengan pendekatan CAI (Computer 


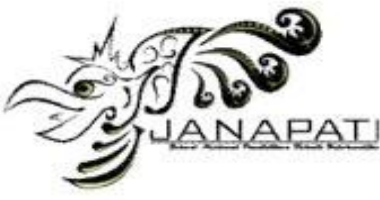

Assisted Instruction), dan (5) pengujian (tinjauan ahli dan uji coba). Teknik pengumpulan data dapat dilihat pada Tabel 3.

Tabel 3 Teknik Pengumpulan Data

\begin{tabular}{|c|l|l|l|}
\hline No & \multicolumn{1}{|c|}{ Jenis Data } & Metode & \multicolumn{1}{c|}{ Sumber Data } \\
\hline 1 & $\begin{array}{l}\text { Informasi } \\
\text { tentang sumber } \\
\text { belajar }\end{array}$ & Angket & $\begin{array}{l}\text { Guru Mata Pelajaran } \\
\text { Videografi }\end{array}$ \\
\hline 2 & $\begin{array}{l}\text { Karakteristik } \\
\text { peserta didik }\end{array}$ & Angket & $\begin{array}{l}\text { Peserta didik kelas X } \\
\text { Desain Komunikasi } \\
\text { Visual 1 di SMKN 1 } \\
\text { Sukasada }\end{array}$ \\
\hline 3 & $\begin{array}{l}\text { Kevalidan e- } \\
\text { modul }\end{array}$ & Angket & $\begin{array}{l}\text { Ahli isi pembelajaran, ahli } \\
\text { desain pembelajaran, dan } \\
\text { ahli media pembelajaran }\end{array}$ \\
\hline 4 & $\begin{array}{l}\text { Respon guru } \\
\text { dan peserta } \\
\text { didik }\end{array}$ & Angket & $\begin{array}{l}\text { Guru Mata Pelajaran } \\
\text { Videografi dan peserta } \\
\text { didik kelas X Desain } \\
\text { Komunikasi Visual 1 di } \\
\text { SMKN 1 Sukasada }\end{array}$ \\
\hline
\end{tabular}

Pada kegiatan observasi guna mendapat informasi sumber belajar dan karakteristik pembelajar, digunakan jenis angket terbuka. Melalui metode angket ini peneliti mengetahui masalah yang terjadi ketika pembelajaran berlangsung terkait sumber belajar, materi, media, dan ketertarikan siswa dalam pembelajaran videografi. Uraian singkat tentang teknis analisis data yang digunakan dalam penelitian ini adalah sebagai berikut.

1. Analisis data kevalidan e-modul

Rumus yang digunakan menghitung persentase masing-masing subyek sebagai berikut ${ }^{[11]}$.

Persentase $=\sum \frac{\text { (Jawaban } \mathrm{x} \text { bobot tiap pilihan })}{\mathrm{n} \text { x bobot tertinggi }} \times 100 \%$

Keterangan :

$\sum=$ jumlah

$\mathrm{n}=$ jumlah seluruh item angket

Selanjutnya, untuk menghitung persentase keseluruhan subjek digunakan rumus ${ }^{[11]}$.

Persentase $=(\mathrm{F}: \mathrm{N})$

Keterangan :

$\mathrm{F}=$ jumlah persentase keseluruhan subjek

$\mathrm{N}=$ banyak subjek

Untuk dapat memberikan makna dan pengambilan keputusan maka digunakan ketetapan terhadap hasil review dan uji coba produk sebagai berikut.

Tabel 4 Konversi Tingkat Pencapaian Dengan Skala $5^{[1]]}$

\begin{tabular}{|l|l|l|}
\hline $\begin{array}{c}\text { Tingkat } \\
\text { Pencapaian } \\
(\%)\end{array}$ & Kualifikasi & \multicolumn{1}{|c|}{ Keterangan } \\
\hline $90-100$ & Sangat baik & Tidak perlu direvisi \\
\hline $75-89$ & Baik & Sedikit direvisi \\
\hline $65-74$ & Cukup & Direvisi secukupnya \\
\hline $55-64$ & Kurang & Banyak hal yang direvisi \\
\hline
\end{tabular}

p-ISSN 2089-8673 | e-ISSN 2548-4265

Jurnal Nasional Pendidikan Teknik Informatika (JANAPATI)

Volume 6, Nomor 1, Maret 2017

\begin{tabular}{|c|l|l|}
\hline $\begin{array}{c}\text { Tingkat } \\
\text { Pencapaian } \\
(\%)\end{array}$ & Kualifikasi & \multicolumn{1}{|c|}{ Keterangan } \\
\hline $0-54$ & $\begin{array}{l}\text { Sangat } \\
\text { kurang }\end{array}$ & $\begin{array}{l}\text { Diulangi membuat } \\
\text { produk }\end{array}$ \\
\hline
\end{tabular}

2. Analisis data respon guru dan siswa

Untuk melakukan perhitungan analisis data respon maka didasarkan pada rata-rata kelas $(\bar{x})$ dari respon siswa, Mi, SDi. Rata-rata kelas dari skor respon siswa dihitung dengan rumus ${ }^{[6]}$.

$\bar{x}=\frac{\sum x}{N}$

Keterangan:

$\bar{x}=$ Rata - rata kelas untuk skor respon siswa

$\sum x=$ Jumlah skor respon siswa

$\mathrm{N}$ = Banyaknya siswa

Sedangkan untuk mencari mean ideal (Mi) dan standar deviasi ideal (SDi) digunakan rumus sebagai berikut ${ }^{[4]}$ :

$M i=\frac{1}{2}($ skor maksimal + skor terendah $) ..$.

$S D i=\frac{1}{6}($ skor terting $i+$ skor terendah $)$...

Rata-rata kelas $(\bar{x})$ dari skor respon siswa kemudian dikategorikan dengan menggunakan pedoman yang disajikan pada Tabel 5 .

Tabel 5 Kriteria Penggolongan Respon ${ }^{[6]}$

\begin{tabular}{|l|l|c|}
\hline No & \multicolumn{1}{|c|}{ Interval } & Kategori \\
\hline 1 & $\mathrm{Mi}+1,5 \mathrm{SDi} \leq \bar{x}$ & Sangat Positif \\
\hline 2 & $\begin{array}{l}\mathrm{Mi}+0,5 \mathrm{SDi} \leq \bar{x}<\mathrm{Mi}+1,5 \\
\mathrm{SDi}\end{array}$ & Positif \\
\hline 3 & $\begin{array}{l}\mathrm{Mi}-0,5 \mathrm{SDi} \leq \bar{x}<\mathrm{Mi}+0,5 \\
\mathrm{SDi}\end{array}$ & Kurang Positif \\
\hline 4 & $\mathrm{Mi}-1,5 \mathrm{SDi} \leq \bar{x}<\mathrm{Mi}-1,5$ & Negatif \\
$\mathrm{SDi}$ & $\bar{x}<\mathrm{Mi}-1,5 \mathrm{SDi}$ & Sangat Negatif \\
\hline
\end{tabular}

\section{PEMBAHASAN}

Pengembangan e-modul videografi memiliki tujuan untuk membantu penambahan sumber belajar, media pembelajaran, dan diharapkan dapat meningkatkan pemahaman materi pelajaran videografi selama proses belajar mengajar di kelas. Berdasarkan hasil observasi awal yang dilakukan, dapat diketahui bahwa kurangnya sumber belajar berupa modul ajar/ buku khusus videografi yang terstruktur dengan baik sebagai panduan dalam proses belajar mengajar di sekolah maupun di luar sekolah, siswa hanya mengandalkan materi dari guru karena susah mencari materi yang sesuai dengan tuntutan kurikulum. Hal ini berdampak terhadap kurangnya tingkat pemahaman peserta didik dan pembelajaran cenderung berpusat pada guru, berbanding terbalik dengan penerapan kurikulum KTSP yang mengutamakan kegiatan pembelajaran berpusat pada siswa (student center). Akibatnya proses belajar mengajar menjadi kurang efektif dan tidak menarik bagi siswa, sehingga pengembangan e-modul berbasis web yang dikemas 


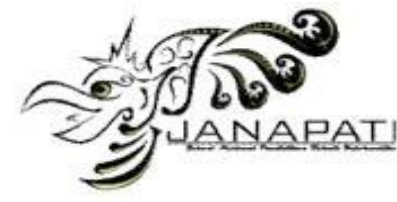

dengan berbagai penyajian materi yang lebih konkret, nyata, dan dilengkapi simulasi pendukung pembelajaran sesuai dengan perkembangan teknologi terkini sangat diperlukan.

Selain itu pengembangan $e$-modul mata pelajaran videografi menggunakan model project based learning (PJBL) yang bertujuan agar tahapan-tahapan pembelajaran yang ada di dalam $e$-modul dapat terstruktur dan terarah. Sesuai dengan tahapan pada desain penelitian yang digunakan (Dick and Carey), tahapan pertama yang dilakukan adalah menentukan mata pelajaran yang menjadi obyek pengembangan, yakni mata pelajaran videografi. Tahapan kedua adalah tahap analisis terhadap isi kebutuhan, untuk menganalisis segala sesuatu yang dibutuhkan dalam pengembangan, yaitu: (a) tujuan mata pelajaran dan karakteristik mata pelajaran, (b) sumber belajar, (c) karakteristik pembelajar. Tahapan ketiga adalah tahap proses proses mengembangkan draft meliputi penyusunan draft modul dan perancangan e-modul, pada tahap ini menentukan Standar Kompetensi (SK), Kompetensi Dasar (KD) dan Indikator pembelajaran yang akan dikembangakan dalam draft modul dan e-modul. Kegiatan penyusunan modul meliputi pengumpulan bahan/materi pelajaran, pengetikan bahan ajar, dan penyusunan materi sesuai kompetensi yang diharapkan.

Tahapan keempat yaitu tahapan skema implementasi media dengan pendekatan CAI (Computer Assisted Instruction) pada tahap ini dilakukan perancangan sistem seperti membuat hak akses masuk ke halaman mata pelajaran, menyusun tampilan masing-masing pengguna (admin, guru dan siswa), mengatur tampilan kegiatan pembelajaran, serta menerapkan modul ke sistem $e$-modul. mengintegrasikan fitur Moodle pada e-modul meliputi penerapan hasil modul ke dalam aplikasi Moodle hingga menjadi produk akhir berupa e-modul. Pengembangan pada fitur Moodle disesuaikan dengan kerangka modul yang digunakan dan berisikan implementasi tahapan project based learning pada e-modul. Skema implementasi emodul dengan pendekatan CAI diterapkan dengan mengintegrasikan fitur yang ada pada moodle agar kegiatan pembelajaran berlangsung secara bertahap sesuai dengan tahapan pembelajaran Project Based Learning.

Tahap kelima adalah pengujian (tinjuan ahli dan uji coba), yang dilakukan dengan menguji coba e-modul sesuai dengan peran dan fungsinya dalam proses pembelajaran untuk mengetahui sejauh mana manfaat produk yang dikembangkan. Tahapan uji coba dimulai dari review para ahli, kemudian dilanjutkan dengan uji coba perorangan, kelompok kecil, dan uji lapangan. Uji ahli yang pertama dilakukan adalah uji ahli isi pembelajaran. Setelah selesai melakukan uji ahli isi, kemudian dilanjutkan dengan uji ahli desain dan ahli media pembelajaran.

Hasil penilaian ahli isi berdasarkan angket menunjukkan bahwa tingkat pencapaian dari e-modul adalah "SESUAI" dan layak untuk dilanjutkan. Hal tersebut mengindikasikan bahwa materi pelajaran yang diimplementasikan dalam e-modul sudah relevan untuk digunakan dalam pembelajaran videografi.
p-ISSN 2089-8673 | e-ISSN 2548-4265

Jurnal Nasional Pendidikan Teknik Informatika (JANAPATI)

Volume 6, Nomor 1, Maret 2017
Materi pelajaran yang memadukan sajian materi dari beberapa sumber buku sebagai referensi pembelajaran dinyatakan valid dan sudah sesuai dengan indikator dan tujuan pembelajaran pada silabus videografi Desain Komunikasi Visual. Karakteristik materi pelajaran videografi yang cenderung mengarah praktikum, pada e-modul sudah dipaparkan dengan bantuan visualisasi melalui gambar dan video sehingga memudahkan pemahaman materi oleh siswa.

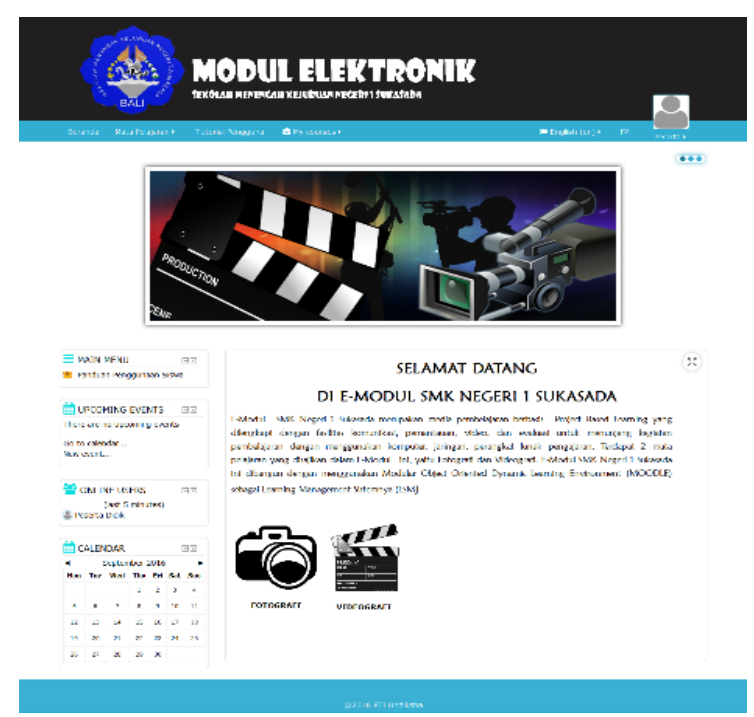

Gambar 2. Halaman Utama Pengguna

Hasil penilaian ahli desain pembelajaran terhadap produk pengembangan e-modul yang terdiri dari kelayakan isi, penyajian, tahap pembelajaran model project based learning, dan model pembelajaran sudah dinyatakan "SESUAI" dan layak untuk dilanjutkan. Hal tersebut mengindikasikan bahwa penerapan model pembelajaran project based learning dalam emodul layak untuk digunakan dalam pembelajaran videografi. Melalui penerapan langkah-langkah model project based learning dalam pembelajaran membuat siswa lebih aktif melalui proyek yang diberikan pada masing-masing kegiatan belajar. Selain itu project based learning memberikan pengalaman kepada peserta didik melalui pembelajaran dan praktik dalam mengorganisasi proyek, dan membuat alokasi waktu dan sumber-sumber lain seperti perlengkapan untuk menyelesaikan tugas. Masukan ahli desain seperti waktu pengerjaan proyek disesuaikan dengan tingkat kesulitan proyek telah dilakukan revisi melalui pemeriksaan kembali tingkat kesulitan proyek dan memberikan rentang waktu yang cukup untuk masing-masing tingkat kesulitan proyek.

Hasil penilaian ahli media pembelajaran yang terdiri dari penggunaan bahasa dan keterbacaan, grafis, desain tampilan emodul, efektivitas, dan media yang dikembangkan dalam emodul videografi telah dinyatakan "SESUAI" dan layak untuk dilanjutkan. Media pembelajaran dalam e-modul yang disajikan 


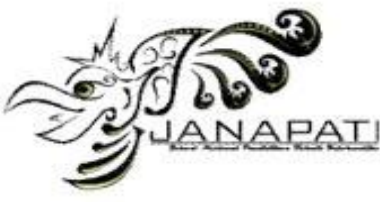

dalam bentuk teks, gambar, animasi, ataupun video disajikan dengan tepat dan jelas, sehingga siswa dengan mudah dapat belajar dan memahami videografi. Hasil penilaian ahli media mengindikasikan bahwa produk e-modul yang sudah dikembangkan layak untuk digunakan dalam pembelajaran videografi. Dari evaluasi ahli media, terdapat saran yang diberikan seperti : penambahan ketentuan pengerjaan tes formatif yang mensyaratkan siswa harus mendapatkan nilai minimal sesuai dengan passing grade agar bisa lanjut ke kegiatan pembelajaran selanjutnya. Revisi telah dilakukan penulis dengan menambahkan ketentuan di awal sebelum siswa memulai mengerjakan tes formatif agar siswa mengetahui prasyarat yang harus dilewati untuk bisa melanjutkan ke kegiatan pembelajaran selanjutnya.

Langkah selanjutnya yaitu melakukan implementasi yang meliputi uji perorangan, uji kelompok kecil, uji lapangan, uji respon guru, dan uji respon siswa. Subjek uji perorangan adalah tiga orang siswa kelas X Desain Komunikasi Visual. Dari hasil angket uji coba yang diisi oleh masing-masing siswa, terdapat satu orang siswa memberikan tanggapan sangat baik $(33,33 \%)$, dua orang siswa yang memberikan tanggapan baik $(66,67 \%)$, dan tidak ada siswa yang memberikan tanggapan cukup, kurang, maupun sangat kurang. Rata-rata penilaian siswa adalah 85,33\%. Jika dikonversikan ke dalam tabel konversi termasuk dalam kategori baik. Revisi pada tahap uji coba perorangan ini hanya dengan perbaikan kesalahan ketik. Penilaian uji coba perorangan memperoleh hasil baik dari kategori tertinggi yaitu sangat baik. Berdasarkan pengamatan langsung dan wawancara dengan guru pengajar videografi, responden uji coba perorangan ini adalah siswa kelas $\mathrm{X}$ yang baru menguasai pengoperasian komputer dasar, sehingga ketika dilakukan uji coba siswa masih perlu beradaptasi dengan penggunaan e-modul dalam pembelajaran. Solusi pada kegiatan uji coba perorangan ini dilakukan peneliti dengan mengarahkan siswa untuk membaca tutorial pengguna yang sudah terdapat pada e-modul dan mengajarkan cara penggunaannya.

Tabel 6 Rekapitulasi Penilaian Pada Uji Coba Perorangan

\begin{tabular}{|c|c|c|}
\hline $\begin{array}{c}\text { Konversi tingkat } \\
\text { pencapaian }\end{array}$ & $\begin{array}{c}\text { Persentase } \\
(\%)\end{array}$ & $\begin{array}{c}\text { Jumlah Responden } \\
\text { (orang) }\end{array}$ \\
\hline Sangat Baik & $33,33 \%$ & 1 \\
\hline Baik & $66,67 \%$ & 2 \\
\hline Cukup & $0 \%$ & 0 \\
\hline Kurang & $0 \%$ & 0 \\
\hline Sangat Kurang & $0 \%$ & \\
\hline
\end{tabular}

p-ISSN 2089-8673 | e-ISSN 2548-4265

Jurnal Nasional Pendidikan Teknik Informatika (JANAPATI)

Volume 6, Nomor 1, Maret 2017

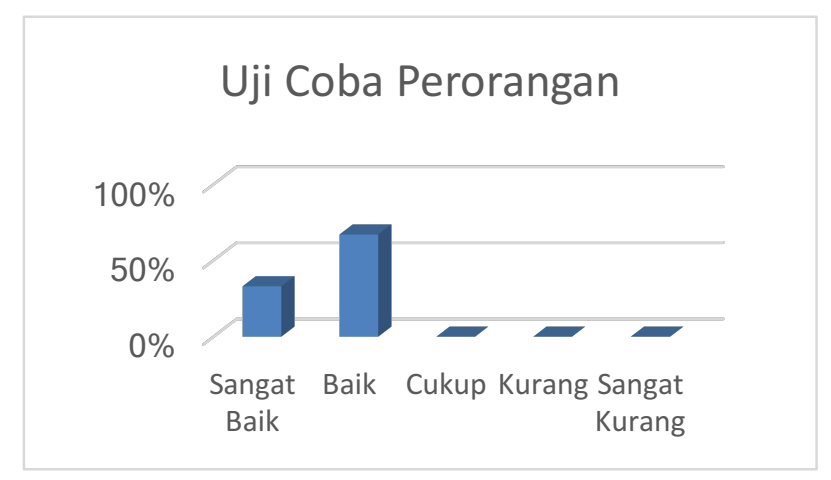

Gambar 3. Grafik Hasil Rekapitulasi Uji Perorangan

Setelah uji perorangan selesai dan direvisi, maka dilanjutkan dengan uji kelompok kecil. Uji kelompok kecil dilakukan oleh dua belas orang siswa kelas $\mathrm{X}$ Desain Komunikasi Visual. Dari hasil angket uji coba kelompok kecil yang diisi oleh masing-masing siswa, terdapat empat orang siswa memberikan tanggapan sangat baik $(33,33 \%)$, delapan orang siswa memberikan tanggapan baik $(66,67 \%)$, dan tidak ada siswa yang memberikan tanggapan cukup, kurang, maupun sangat kurang. Rata-rata penilaian dua belas orang siswa adalah $87,42 \%$. Jika dikonversikan ke dalam tabel konversi termasuk dalam kategori baik. Pada uji coba kelompok kecil terdapat beberapa hal yang menjadi penyebab siswa belum mengerti pengoperasian e-modul berdasarkan pengamatan di lapangan yaitu siswa belum paham penggunaan komputer dasar dengan baik, selama ini metode pembelajaran yang dilakukan siswa adalah penggunaan modul cetak sehingga ini merupakan pengalaman awal menggunakan pembelajaran berbasis komputer, sehingga membutuhkan penyesuaian dan penjelasan lebih lengkap tentang e-modul. Namun beberapa temuan tersebut sudah dicoba diatasi oleh peneliti dengan mendampingi siswa secara langsung dalam pengoperasian e-modul dan penggunaan tutorial pengoperasian e-modul.

Tabel 7 Rekapitulasi Penilaian Pada Uji Coba Kelompok Kecil

\begin{tabular}{|c|c|c|}
\hline $\begin{array}{c}\text { Konversi tingkat } \\
\text { pencapaian }\end{array}$ & $\begin{array}{c}\text { Persentase } \\
(\%)\end{array}$ & $\begin{array}{c}\text { Jumlah Responden } \\
\text { (orang) }\end{array}$ \\
\hline Sangat Baik & $33,33 \%$ & 4 \\
\hline Baik & $66,67 \%$ & 8 \\
\hline Cukup & $0 \%$ & 0 \\
\hline Kurang & $0 \%$ & 0 \\
\hline Sangat Kurang & $0 \%$ & 0 \\
\hline
\end{tabular}




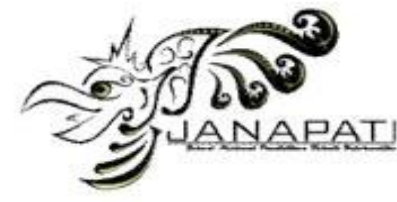

\section{Uji Coba Kelompok Kecil}

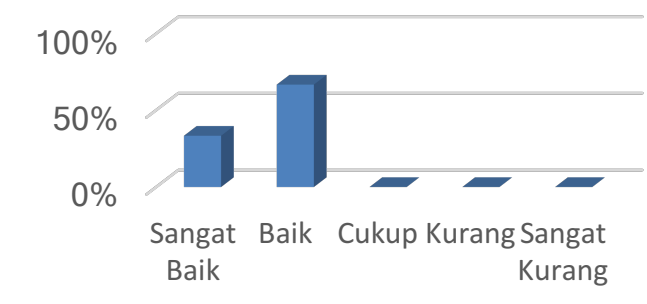

Gambar 4. Grafik Rekapitulasi Uji Kelompok Kecil

Setelah uji coba kelompok kecil selesai dilanjutkan dengan uji lapangan yang dilakukan oleh dua puluh orang siswa kelas X Desain Komunikasi Visual di SMK Negeri 1 Sukasada. Dari hasil angket uji coba diperoleh dua belas orang siswa memberikan tanggapan sangat baik (60\%), delapan orang siswa memberikan tanggapan baik (40\%), dan tidak ada siswa yang memberikan tanggapan cukup, kurang, maupun sangat kurang. Rata-rata penilaian keseluruhan responden uji lapangan adalah 90,05\%. Jika dikonversikan ke dalam tabel konversi tingkat pencapaian termasuk dalam kategori sangat baik dan tidak perlu revisi pada e-modul. Berdasarkan temuan di lapangan, penggunaan e-modul dalam proses kegiatan belajar mengajar di kelas dapat membantu siswa memahami materi lebih cepat dan meningkatkan interaksi antar guru dan siswa. Melalui isi materi yang disajikan dalam bentuk teks, gambar, dan video dalam emodul siswa lebih mudah memahami materi dan sangat membantu dalam pengerjaan proyek. Keberhasilan model pembelajaran project based learning untuk meningkatkan aktivitas belajar siswa disebabkan oleh penerapan model project based learning yang membantu siswa terlibat secara aktif mengikuti pembelajaran. Model project based learning memberikan kesempatan siswa untuk belajar menyenangkan, sehingga menumbuhkan minat siswa untuk belajar dan mendorong siswa untuk mengembangkan keterampilannya.

Tabel 8 Rekapitulasi Penilaian Pada Uji Coba Lapangan

\begin{tabular}{|c|c|c|}
\hline $\begin{array}{c}\text { Konversi tingkat } \\
\text { pencapaian }\end{array}$ & $\begin{array}{c}\text { Persentase } \\
(\%)\end{array}$ & $\begin{array}{c}\text { Jumlah Responden } \\
\text { (orang) }\end{array}$ \\
\hline Sangat Baik & 60,00 & 12 \\
\hline Baik & 40,00 & 8 \\
\hline Cukup & $0 \%$ & 0 \\
\hline Kurang & $0 \%$ & 0 \\
\hline Sangat Kurang & $0 \%$ & 0 \\
\hline
\end{tabular}

p-ISSN 2089-8673 | e-ISSN 2548-4265

Jurnal Nasional Pendidikan Teknik Informatika (JANAPATI)

Volume 6, Nomor 1, Maret 2017

\section{Uji Coba Lapangan}

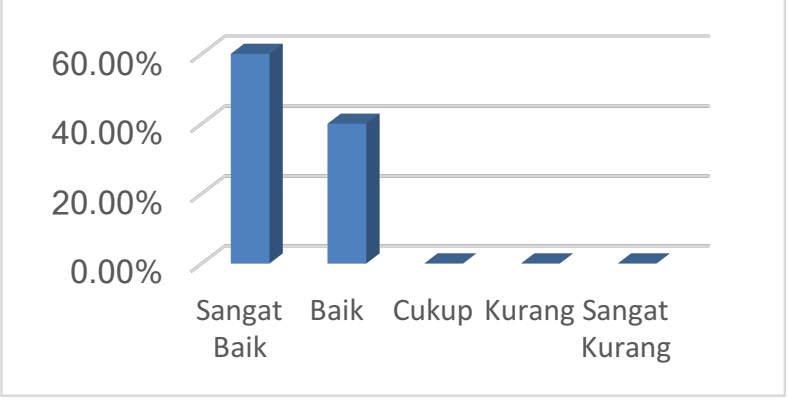

Gambar 5. Grafik Hasil Rekapitulasi Uji Lapangan

Setelah hasil uji lapangan selesai dilakukan, selanjutnya dilakukan pengambilan respon guru terhadap pengembangan emodul pada mata pelajaran videografi. Uji respon guru dilakukan oleh satu orang responden yaitu Bapak Wayan Mudita, S.Pd dan memperoleh rata-rata sebesar 50, jika dikonversikan ke dalam tabel kriteria penggolongan respon maka hasilnya termasuk dalam kategori sangat positif. Proses uji selanjutnya dilakukan dengan pengambilan respon siswa. Subjek uji coba respon siswa adalah terdiri dari 20 orang siswa kelas X Desain Komunikasi Visual yang telah belajar menggunakan e-modul. Hasil angket respon siswa terhadap pengembangan e-modul videografi memperoleh rata-rata sebesar 67,65, jika dikonversikan ke dalam tabel kriteria penggolongan respon maka hasilnya termasuk dalam kategori sangat positif. Berdasarkan hasil respon guru dan siswa dapat dikategorikan membantu siswa dalam memahami mata pelajaran videografi dan berhasil mengatasi permasalahan tidak adanya modul ajar.

Berdasarkan pembahasan di atas, penilaian-penilaian yang dilakukan oleh ahli isi, ahli desain pembelajaran, ahli media, uji coba perorangan, uji coba kelompok kecil, uji lapangan, maupun hasil respon guru dan siswa termasuk dalam kategori baik dan mendapat respon positif. Berdasarkan penilaian tersebut, secara garis besar pengembangan e-modul berbasis model pembelajaran project based learning pada mata pelajaran videografi untuk siswa kelas $\mathrm{x}$ desain komunikasi visual di SMK Negeri 1 Sukasada telah menunjukkan adanya keberhasilan dan layak digunakan sebagai sumber belajar untuk siswa kelas X Desain Komunikasi Visual di SMK Negeri 1 Sukasada. Hal ini didukung pula dengan beberapa pernyataan siswa yaitu keberadaan e-modul videografi sangat membantu dalam proses pembelajaran, e-modul membuat siswa lebih antusias dalam belajar videografi, maupun memudahkan siswa memahami materi lebih cepat dan sangat efektif dalam pelajaran. Melalui penerapan e-modul videografi ini diharapkan dapat membantu guru selama proses pembelajaran dan masalah selama proses pembelajaran terkait sumber belajar 


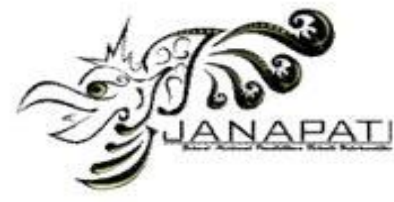

mampu teratasi, intensitas belajar siswa meningkat, dan membantu siswa menjadi lebih aktif dalam proses belajar mengajar secara mandiri maupun berkelompok.

\section{PENUTUP}

Berdasarkan hasil penelitian dan pembahasan pada penelitian Pengembangan E-Modul Berbasis Model Pembelajaran Project Based Learning Pada Mata Pelajaran Videografi untuk Siswa Kelas X Desain Komunikasi Visual di Smk Negeri 1 Sukasada, maka penulis dapat menarik kesimpulan sebagai berikut. (1) Hasil rancangan dan implementasi Pengembangan E-Modul Berbasis Model Pembelajaran Project Based Learning Pada Mata Pelajaran Videografi untuk Siswa Kelas X Desain Komunikasi Visual di Smk Negeri 1 Sukasada menggunakan tahapan model project based learning sudah dinyatakan berhasil diterapkan. Hal ini dapat dilihat dari rata-rata persentase berdasarkan hasil pengujian yang telah dilakukan. Secara umum siswa terlihat antusias dan lebih aktif selama proses pembelajaran berlangsung. (2) Respon guru terhadap Pengembangan EModul Berbasis Model Pembelajaran Project Based Learning Pada Mata Pelajaran Videografi untuk Siswa Kelas X Desain Komunikasi Visual di Smk Negeri 1 Sukasada didapatkan ratarata sebesar 50. Jika dikonversikan ke dalam tabel kriteria penggolongan respon maka hasilnya termasuk dalam kategori sangat positif. Sedangkan untuk respon siswa terhadap pengembangan e-modul videografi memperoleh rata-rata sebesar 67,65. Jika dikonversikan ke dalam tabel kriteria penggolongan respon maka hasilnya termasuk dalam kategori sangat positif.

Berdasarkan pengamatan penulis, terdapat beberapa hal yang dapat dijadikan bahan pertimbangan untuk ditindak lanjuti. (1) Bagi pengembang e-modul selanjutnya agar dapat mengatur e-modul lebih user friendly atau mudah digunakan oleh pengguna yang masih belum terbiasa dengan pembelajaran berbasis komputer. Selain itu, dapat mengatur agar setiap tahapan pembelajaran Project Based Learning ada fitur yang bisa memberikan tantangan baik berupa games atau bentuk lainnya agar siswa tidak merasa bosan ketika sedang belajar dengan menggunakan e-modul. (2) Produk e-modul berbasis model pembelajaran project based learning pada mata pelajaran videografi untuk siswa kelas $\mathrm{x}$ desain komunikasi visual di SMK Negeri 1 Sukasada yang dikembangkan belum
p-ISSN 2089-8673 | e-ISSN 2548-4265

Jurnal Nasional Pendidikan Teknik Informatika (JANAPATI)

Volume 6, Nomor 1, Maret 2017 sampai pada tahap pengukuran hasil belajar siswa. Oleh karena itu, perlu diadakan pengkajian lebih lanjut mengenai efektivitas penggunaan e-modul berkaitan dengan pengukuran hasil belajar siswa menggunakan e-modul ini melalui penelitian eksperimen.

\section{REFERENSI}

[1] Arsyad, A. (2009). Media Pembelajaran. Jakarta: Raja Grafindo Persada.

[2] Dewi, N. K., Garminah, N. N., \& Pudjawan, K. (2013). Pengaruh Model Pembelajaran Berbasis Proyek (Project- Based Learning) Terhadap Hasil Belajar IPA Siswa Kelas IV SD N 8 Banyuning.

[3] Fausih, M., \& Danang, T. (2015). Pengembangan Media E-modul Mata Pelajaran Produktif Pokok Bahasan "Instalasi Jaringan LAN (Local Area Network)" untuk Siswa Kelas XI Jurusan Teknik Komputer Jaringan di SMK Negeri 1 Labang Bangkalan Madura.

[4] Gunadharma, A. (2011). Pengembangan Modul Elektronik sebagai Sumber Belajar Untuk Mata Kuliah Multimedia Design Pengembangan Modul Elektronik sebagai Sumber Belajar Untuk Mata Kuliah Multimedia Design. Skripsi (tidak diterbitkan). Jurusan Teknologi Pendidikan, Fakultas Ilmu Pendidikan, Universitas Negeri Jakarta.

[5] Jagantara, I M., Adnyana, P. B., \& Widiyanti, N. L. (2014). Pengaruh Model Pembelajaran Berbasis Proyek (Project Based Learning) Terhadap Hasil Belajar Biologi Ditinjau Dari Gaya Belajar Siswa SMA. e-Journal Program Pascasarjana Universitas Pendidikan Ganesha.

[6] Nurkancana, W., \& Sunarta, P. (1992). Evaluasi Hasil Belajar. Surabaya: Usaha Nasional.

[7] Pawana, M. G. (2014). Pengembangan Multimedia Interaktif Berbasis Proyek Dengan Model Addie Pada Materi Pemrograman Web Siswa Kelas X Semester Genap di SMK Negeri 3 Singaraja. e-Journal Program Pascasarjana Universitas Pendidikan Ganesha.

[8] Santyasa, I W. (2009). Metode Penelitian Pengembangan dan Teori Pengembangan Modul. Universitas Pendidikan Ganesha.

[9] Suarsana, I M., \& Mahayukti, G. A. (2013). Pengembangan E-modul Berorientasi Pemecahan Masalah untuk Meningkatkan Keterampilan Berpikir Kritis Mahasiswa. Jurnal Nasional Pendidikan Teknik Informatika (JANAPATI).

[10] Sugiyono. (2008). Metode Penelitian Kuantitatif, Kualitatif dan R \& D. Bandung: Alfabeta.

[11] Tegeh, I M., \& Kirna, I M. (2010). Metode Penelitian Pengembangan Pendidikan. Singaraja: Undiksha.

[12] Warsita, B. (2008). Teknologi Pembelajaran : Landasan dan Aplikasinya. Jakarta: Rineka Cipta.

[13] Wicaksono, A. R., Winarno, W. W., \& Sunyoto, A. (2015). Perancangan dan Implementasi E-learning Pendukung Project Based Learning. Seminar Nasional Teknologi Informasi dan Komunikasi (SENTIKA).

[14] Wijayanto, \& Zuhri, M. S. (2014). Pengembangan E-modul Berbasis Flip Book Maker dengan Model Projet Based Learning untuk Mengembangkan Kemampuan Pemecahan Masalah Matematika . Prosiding Mathematics and Sciences Forum.

[15] Wiyoko, T., Sarwanto, \& Raharjo, D. T. (2014). Pengembangan Media Pembelajaran Fisika Modul Elektronik Animasi Interaktif untuk Kelas XI SMA Ditinjau dari Motivasi Belajar Siswa. Jurnal Pendidikan Fisika. 